\title{
中学生における生活の循環構造
}

田中 良 ${ }^{1.2}$ 野井 真吾

\section{Cycle structure about life habits in junior high school students}

\section{Ryo Tanaka ${ }^{1,2}$ and Shingo Noi}

\begin{abstract}
The purpose of this study was to examine the cycle structure about life habits in junior high school students. The participants were 9,167 children from 1st to 3rd grader in Setagaya city. Survey items included life habits (breakfast intake habit, sleeping habit, exercise habit, electronic media usage habit, and so on) and subjective symptoms of fatigue. We analyzed validities of "life before start of class" "subjective symptoms at school" and "life after school". After that the cycle structure about those was analyzed by using structural equation modeling, using multiple group structural equation modeling to consider about sex difference. The main results in this study were as follows. It was confirmed that one day living have Cycle structure and not sex difference. Additionally, it was also confirmed that path coefficient from "life after school" to "life before start of class" was highest in cyclic structure about life habits in junior high school. All models exhibited good conformity modeling and confirmed validities of three latent variable and cycle structure about life habits in junior high school students.

These finding indicated that improvement of "life after school" is the most influential for good lifestyle habit. Although it has less impact than "life after school" improvement of "life before start of class" and "subjective symptoms at school" also have significance.
\end{abstract}

Key words : junior high school student, structural equation modeling, lifestyle habit, subjective symptoms, cycle structure

中学生，構造方程式モデリング，生活習慣，自覚症状，循環モデル

\section{I 緒 言}

保育・教育現場の教師を対象に子どもの「から だのおかしさ」の害感を調査した野井ほか (2016) は,「すぐ“疲れた”という」子どもが“最近増え ている”との回答率がすべての学校段階（保育園, 幼稚園, 小学校, 中学校, 高等学校) で高い様子 を報告し, 病気や障害ではないものの, さりとて
健康ともいえない問題の解決の必要性を指摘して いる.これらの問題の背景に子ども生活習慣の乱 れが存在することは容易に想像でき, 子どもの生 活習慣を検討した報告は多数散見できる，例え ば，小・中学生 1,352 名を対象に, 朝食摂取状況 と基本的生活習慣との関連を検討した林ほか （2008）は，朝食を毎日摂取する者に比して朝食を 欠食する者で就床時刻が遅く,「やる気がでない」

\footnotetext{
日本体育大学大学院博士後期課程

2 日本学術振興会特別研究員

3 日本体育大学

${ }^{1}$ Doctoral Degree Program, Nippon Sport Science University

${ }^{2}$ Research Fellowship for young scientists, Japan Society for the Promotion of Science

${ }^{3}$ Nippon Sport Science University
} 
「いつも眠い」といった不定愁訴の訴えも多い様 子を報告している。 また，中学生の抱えるねむけ 感には, 睡眠時間, 朝食摂取, 放課後の身体活動, 電子メディア利用時間が複合的に関連していると の報告（田中ほか，2017）もある。これらの報告 は, 朝食摂取状況やねむけ感に多くの生活習慣が 関連していることを示唆している。だが一方で, 小澤（2004）は「ライフマネジメント（1日）の風 車モデル」を提示し, 生活習慣は, 生活の一部の 改善があれば風車のように好循環することを指摘 している。実際，春木・川畑（2005）は，朝食を 毎日摂取する者は欠食する者よりも就床時刻が早 い様子を報告している。加えて, 渡邊ほか (2016) は, 朝食を落ち着いてしっかり食べる者は愁訴数 が少ない様子を報告している。これらの報告は, 早い時刻の就床が翌日の朝食の摂取へつながり, 日中の愁訴数も少なくすることを予見させる. 加 えて, 生活習慣が一連の流れでつながりながら循 環的に作用している可能性も示唆している. しか しながら，春木・川畑（2005）は夜の生活が朝の 生活に, 渡邊ほか (2016) は朝の生活が日中の生 活に影響を与えることを明らかにするまでにとど まっており，1日の生活が循環しているかどうか については検討されていない.

そこで本研究では, 中学生における生活（始業 前の生活, 学校での自覚症状, 放課後の生活）の 循環構造を確認することを目的とした。

\section{II 方 法}

\section{1. 対象および期間}

本調查は, 東京都世田谷区の全公立中学校 29 校に在籍する中学生 9,167 名を対象とする悉皆調 查として 2017 年 3 月に実施された。分析には, 回答に欠損がなかった中学生 6,806 名 $(74.2 \%)$ 分のデー夕を用いた。 また, 調査は休日明けとそ れ以外の平日とでは睡眠状況が異なるという Noi and Shikano（2011）の報告を受けて，月曜日を除 く平日の午前中に限って実施した.

\section{2. 調査方法}

本調査では, 自己記入による無記名式調查票を 用いて, 疲労自覚症状と生活状況を調査した.
疲労自覚症状については, 日本産業衛生学会産 業疲労研究会によって作成された 25 項目からな る「自覚症しらべ」(城, 2002) を使用した。この 「自覚症しらべ」は全 25 項目からなる調査票で, 設問は 5 項目ずつの 5 群（I 群：ねむけ感，II群： 不安定感, III 群 : 不快感, $\mathrm{I}$ 群 : だるさ感, V 群 : ぼやけ感)で構成されている，また，この「自覚 症しらべ」は，中学生を対象として使用すること の信頼性と妥当性も検証されている（田中ほか, 2017). 生活状況については, 野井ほか (2008) お よび日本学校保健会（2014）の調査票を参考に, 質問文, 選択肢を一部変更した 16 項目（朝食摂取 状況, 睡眠状況, 身体活動状況, 電子メディア利 用時間等）の設問（表 1）を設定した調査票を作 成し, それらの回答を求めた。 また, 調査票は, 各学校宛に送付し, 回答後は教育委員会を通じて 回収をした。

\section{3. 分析方法}

本研究では, 以下の 2 点を検討した.

1 点目は,「始業前の生活」「学校での自覚症状」 「放課後の生活」の各潜在変数の妥当性の検討で ある.この検討では, 最初に,「自覚症しらべ」に より得られた回答結果から，「まったくあてはま らない」1点,「わずかにあてはまる」 2 点,「すこ しあてはまる」3 点, 「かなりあてはまる」4 点, 「非常によくあてはまる」5点に得点化し, 群別 （ I 〜 V 群）得点を算出した。 その上で,「始業前 の生活」の観測変数には, 朝食摂取状況, 起床時 刻, 始業前の身体活動状況, 寝起きの状況, 排便 状況を, 「学校での自覚症状」の観測変数には, 学 校での眠気, 昼休みの身体活動状況, I 群 : ねむ け感, II 群 : 不安定感, III群 : 不快感, IV 群 : た るさ感, $V$ 群: ぼやけ感を,「放課後の生活」の観 測变数には, 寝つきの状況, 携帯・スマホ利用時 間，ゲーム利用時間，TV 視聴時間， PC・タブレッ 卜利用時間, 就床時刻, 通塾の有無, おけいこご と（スポーツは除く）の有無, 放課後の身体活動 状況の観測变数を設定し, 各潜在変数の妥当性を 検討するために確認的因子分析を行った。なお， 各モデルの修正は，最初にモデルの適合度指標を 確認し, 適合度指標が良好でなかった場合には, 推定值が 0.15 未満の観測変数を除外した。ささら 
表 1 本研究で用いた設問と回答 $(n=6,806)$

\begin{tabular}{|c|c|c|}
\hline & 男子 & 女子 \\
\hline 就床時刻（時：分） & $23: 25 \pm 72.1$ & $23: 33 \pm 72.1$ \\
\hline 起床時刻（時：分） & $6: 58 \pm 39.0$ & $6: 52 \pm 36.0$ \\
\hline ゲーム利用時間（分間） & $103.6 \pm 111.2$ & $69.5 \pm 82.0$ \\
\hline TV 視聴時間（分間） & $117.1 \pm 113.6$ & $134.5 \pm 116.3$ \\
\hline 携帯·スマホ利用時間（分間） & $146.5 \pm 132.4$ & $163.0 \pm 149.5$ \\
\hline PC · タブレット利用時間（分間） & $109.2 \pm 124.4$ & $91.5 \pm 106.5$ \\
\hline I 群：ねむけ感（点） & $11.2 \pm 5.3$ & $12.1 \pm 5.2$ \\
\hline Ｉ群：不安定感（点） & $8.2 \pm 4.4$ & $8.7 \pm 4.5$ \\
\hline 且群：不快感（点） & $7.9 \pm 4.3$ & $8.4 \pm 4.5$ \\
\hline IV群：だるさ感（点） & $8.7 \pm 4.5$ & $9.3 \pm 4.4$ \\
\hline V群：ぼやけ感（点） & $7.9 \pm 4.3$ & $8.4 \pm 4.3$ \\
\hline 朝起きられない者 $(\%)^{a}$ & 44.5 & 52.0 \\
\hline 寝つきが悪い者 $(\%)^{a}$ & 16.0 & 17.5 \\
\hline ほとんど毎日学校で眠くなる者 $(\%)^{b}$ & 21.0 & 24.4 \\
\hline 朝食毎日摂取者 $(\%)^{\mathrm{C}}$ & 85.7 & 84.9 \\
\hline 排便がほとんど毎日朝に出る者（\%) ${ }^{d}$ & 30.0 & 17.3 \\
\hline 始業前身体活動実施者（\%) ${ }^{a}$ & 23.6 & 15.0 \\
\hline 昼休み身体活動実施者 $(\%)^{a}$ & 53.4 & 24.9 \\
\hline 放課後身体活動実施者（\% $)^{a}$ & 72.3 & 52.8 \\
\hline 学習塾利用者 $(\%)^{a}$ & 61.2 & 56.0 \\
\hline おけいこごと（スポーツは除く）利用者 $(\%)^{a}$ & 19.9 & 35.6 \\
\hline
\end{tabular}

a ; 各質問（朝起きられない, 寝つきが悪い, 始業前·昼休み·放課後にからだを動かし た遊びや運動をしますか, 学習塾・おけいこごと「スポーツは除く」に通っています か）に対する選択肢は,「はい」「いいえ」であった.

b ; 「学校でねむくなることはどのくらいありますか」の質問に対する選択肢は,「ない」 「一週間に 1 2 日ある」「一週間に3〜4 日ある」「ほとんど毎日ある」であった.

“; 「曰ごろ朝，食事をしますか」の質問に対する選択肢は，「毎日食べる」「食べる日の 方が多い」「食べない日の方が多い」「ほとんど食べない」であった

d; 「大便（うん己）は，毎日どのようにでますか」の質問に対する選択肢は，「毎日ほと んど朝に出る」「朝ではないが, 毎日ほとんど同じころに出る」「毎日出るが, 同じこ ろではない」「ときどきでないことがある」「数日出ないことがある」であった.

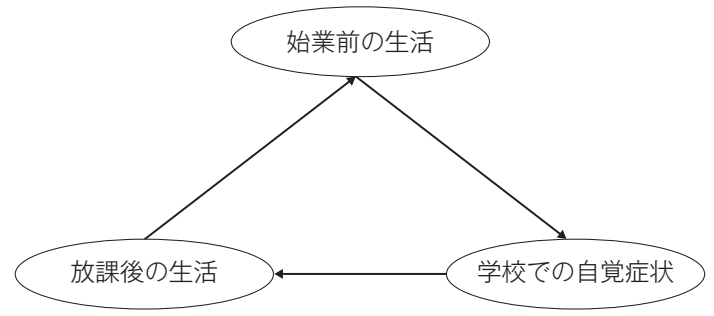

図 1 本研究で設定した仮説モデル

に，各潜在変数における修正指数が最大を示し， かつモデルの改善が見込める場合に限って，それ らの誤差間の共分散を仮定した.

2 点目は, 仮説モデルの妥当性の検討である. この検討では，それぞれの潜在変数をパスでつな いだ仮説モデル（図 1）を作成し, 構造方程式モ デリングを用いて分析した，加えて，仮説モデル
の妥当性が確認された場合には, 性差についても 多母集団同時分析により検討した。多母集団同時 分析では，モデルの構造が同じである配置不変， および，因子負荷量が同じである測定不変の制約 のもと，モデルの適合性を比較した，両検討にお けるパラメーター推定は最尤法を用いた。モデル の適合度指標には, GFI (Goodness of fit index), AGFI (Adjusted GFI), CFI (Comparative FI), RMSEA (Root Mean Square Error of Approximation）の 4 指標を用いた. GFI, AGFI, CFI の指標 は 9.0 以上, RMSEA は 0.08 以下でモデルの適合 が良いと判断することとした。 また，多母集団同 時分析の際には，モデルの相対的な良さを評価す るために AIC (Akaike Information Criterion) も 用いた。

なおこれら一連の統計解析における統計学的 


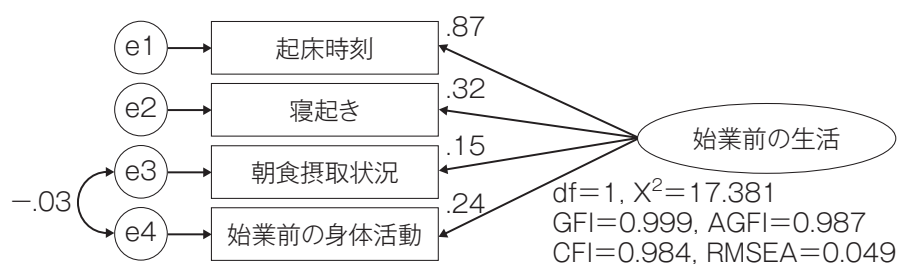

図 2 中学生における「始業前の生活」の因果構造

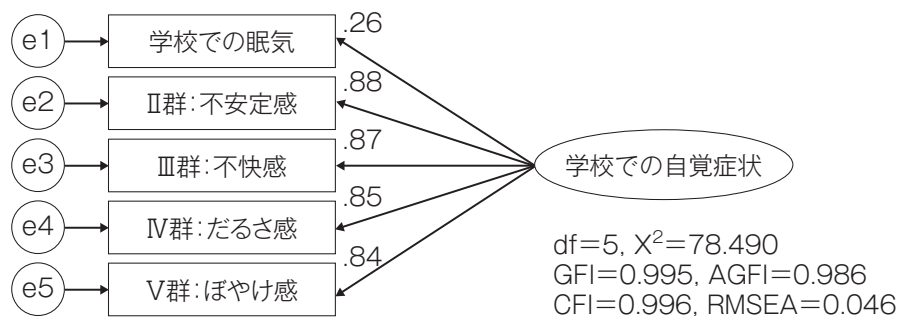

図 3 中学生における「学校での自覚症状」の因果構造

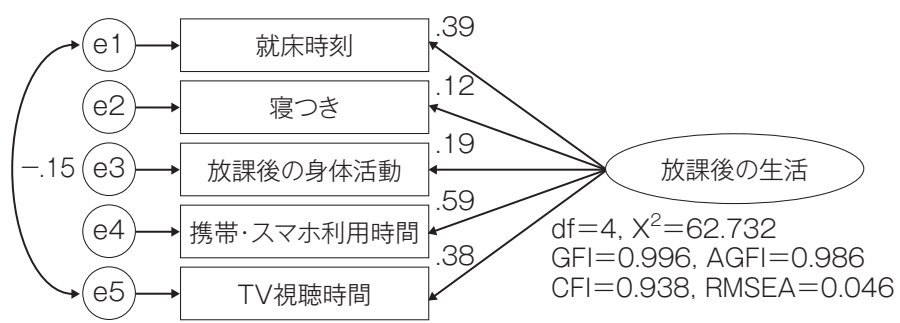

図 4 中学生における「放課後の生活」の因果構造

有意水準は危険率 $5 \%$ 未満とした。

\section{4. 倫理的配慮}

本研究は, 日本体育大学におけるヒトを対象と した実験等に関する倫理審査委員会の承認（承認 番号 : 第 015-H075 号) を得た上で, 世田谷区教育 委員会が主催する校長会の承諾を得て実施され た。また, 対象者に対しては, 調査の趣旨と内容, 参加決定・継続の自由, プライバシーの保護等に ついて，文書による説明を事前に行い, 調査協力 の意志は調査票への回答をもって確認した.

\section{III 結果}

「始業前の生活」「学校での自覚症状」「放課後の 生活」の各潜在変数の妥当性を検討するために, 各潜在変数に対して観測変数を設定し, 確認的因
子分析を行った. その結果, 「始業前の生活」「学 校での自覚症状」「放課後の生活」におけるすべて の観測変数が設定された各モデルの適合度指標は いずれも良好でなかった。そのため，3つの潜在 変数を構成する観測変数のうち, 推定值が 0.15 未満の観測変数 (始業前の生活: 排便状況, 学校 での自覚症状：昼休みの身体活動状況, I 群：ね むけ感, 放課後の生活：おけいごと（スポーツを 除く) ・通塾の有無, ゲーム利用時間, $\mathrm{PC} ・$ タブ レット利用時間）を削除したところ, モデルの適 合度指標は良好となった。 さらに, 修正指数が最 大值を示した誤差間（始業前の生活：朝食摂取 $\Leftrightarrow$ 始業前の身体活動, 放課後の生活: 就床時刻 $\Leftrightarrow \mathrm{TV}$ 視聴時間）に共分散を仮定した結果,「始業前の生 活」「放課後の生活」の適合度指標は最も良好で あった。 各モデルの最終解とその適合度指標は, 図 2，3，4 に示す通りである。モデル適合度指標 


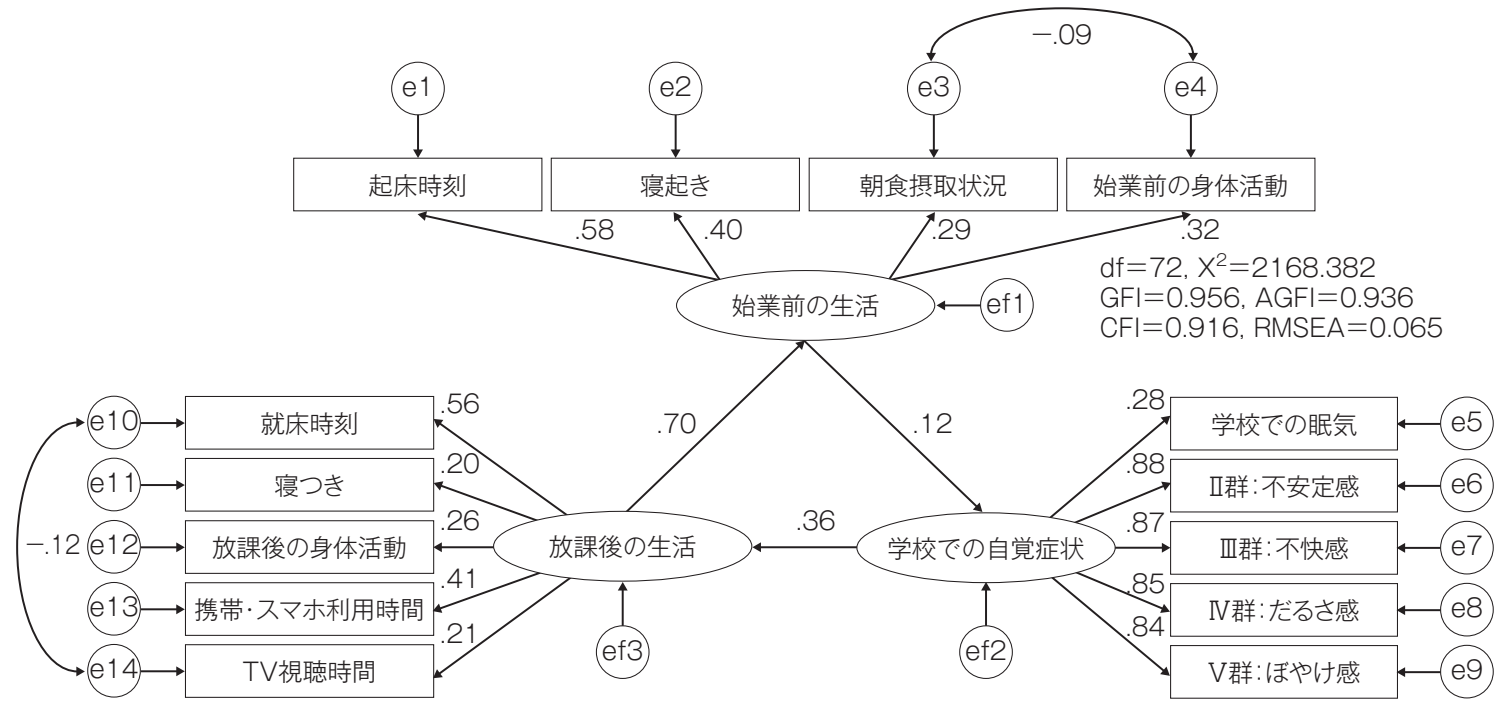

図 5 中学生における「1日の生活」の循環構造

表 2 多母集団同時分析における配置不変・測定不変モデルの適合度

\begin{tabular}{lcccccc}
\hline & $\chi^{2}$ & GFI & AGFI & CFI & RMSEA & AIC \\
\hline 配置不変モデル & 2225.9 & 0.954 & 0.933 & 0.917 & 0.046 & 2357.9 \\
測定不変モデル (因子負荷量不変) & 2245.1 & 0.954 & 0.938 & 0.916 & 0.045 & 2355.1 \\
\hline
\end{tabular}

はすべて良好であり，推定值（標準化推定值）も すべて有意であった。

次に, 妥当性が確認された潜在変数同士をパス でつないだ仮説モデルを作成し, 構造方程式モデ リングで検討した．この検討のために作成したモ デルとその分析結果は, 図 5 の通りである。すべ ての推定值（標準化推定值）は有意であった。モ デルの適合度指標は, GFI $=0.956, \mathrm{AGFI}=0.936$, $\mathrm{CFI}=0.916, \mathrm{RMSEA}=0.065$ で良好であり，3つ の潜在変数（始業前の生活, 学校での自覚症状, 放課後の生活）は, 循環構造にある様子が確認さ れた。続いて，この循環モデルの性差を多母集団 同時分析により検討した。男子におけるモデルの 適合度指標は $\mathrm{GFI}=0.961, \mathrm{AGFI}=0.943, \mathrm{CFI}=$ $0.935, \mathrm{RMSEA}=0.060$, 女子おけるモデルの適合 度指標は $\mathrm{GFI}=0.947, \mathrm{AGFI}=0.923, \mathrm{CFI}=0.892$, RMSEA $=0.071$ であり, 女子の CFI が 0.9 を若 干下回るものの男女別のモデルは良好であった. その後, 配置不変性を検討したところ, 循環モデ ルの適合度指標は $\mathrm{GFI}=0.954, \mathrm{AGFI}=0.933$, $\mathrm{CFI}=0.917, \mathrm{RMSEA}=0.046$ と良好である様子
が示された，続いて，循環モデルの配置不変性が 確認されたため, 同じモデルの測定不変性（因子 負荷量不変）を検討した。その結果，モデルの適 合度指標は良好であり，配置不変性のモデルに比 して, AGFI, RMSEA, AIC が若干ではあるものの より良好である様子も確認された（表 2)。した がって, 本研究では, すべての因子負荷量が等し いとする測定不変モデルが採択された．さらに, 男女間での循環モデルにおける推定值の差の検討

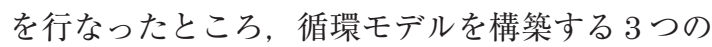
パス（「始業前の生活 $\rightarrow$ 学校での自覚症状」「学校 での自覚症状 $\rightarrow$ 放課後の生活」「放課後の生活 $\rightarrow$ 始業前の生活」）に男女差は認められなかった.

\section{IV 考察}

本研究の対象者は日本学校保健会（2016）によ る全国調査の結果と比較して男女ともに, 遅寝遅 起き傾向を示し, 携帯・スマホ利用時間, $\mathrm{PC} \cdot$ 夕 ブレット利用時間が長く, 学習塾・おけいこごと （スポーツは除く）利用者の割合が多い様子が確 
認された。対して, TV 視聴時間, 朝食摂取状況は, 大差がない様子も確認された（表 1).

このような中学生を対象に実施された本研究で は，最初に「始業前の生活」「学校での自覚症状」 「放課後の生活」の各潜在変数を構成する要因の 妥当性を検討した。その結果,「始業前の生活」は 起床時刻, 寝起きの状況, 朝食摂取状況, 始業前 の身体活動状況により構成される様子が確認され た (図 2).『平成 26 年度児童生徒の健康状態サー ベイランス事業報告書』（日本学校保健会, 2016) では, 中学生において排便状況が良好でない者, 朝食を摂取しない者に比して, 朝食摂取状況が良 好な者で起床時刻から登校までの時間が 5 23 分 間長い様子が報告されている。このうち，排便状 況については確認的因子分析の結果,「始業前の 生活」から除外された項目であったことから本研 究は異なる結果を示したものの, 朝食摂取状況に ついてはそれを支持する結果であった。このよう な報告は, 起床時刻を早めて登校までの時間を確 保することが朝食摂取状況に関連することを示唆 しているものと考える. また,「放課後の生活」は 就床時刻, 寝つきの状況, 放課後の身体活動状況, 携帯・スマホ利用時間, TV 視聴時間で構成される 様子が確認された。女子学生 163 名対象として 就床前 1 時間の行動と睡眠との関連を検討した植 野ほか（2012）は，就寝前にメディアを利用する 者の就床時刻が遅く, 入眠時間は長い様子を報告 している。また，睡眠・概日リズムの指標として 用いられるメラトニンの分泌は夜間の受光で抑制 され (Lewy et al., 1980 ; Brainard et al., 1997 ; Zeitzer et al., 2000), 同じ明るさの光であっても, 成人よりも子どもで約 2 倍抑制される（Higuchi et al., 2014）ことが報告されている。 これらの事 実は，携帯・スマホ利用による受光が就床時刻を 遅延させていることを推測させる，さらに，本研 究の対象者が全国の中学生に比して電子メディア の利用時間が長いことも勘案すると，「放課後の 生活」に携帯・スマホ利用時間, TV 視聴時間, 就 床時刻が含まれる本研究の結果（図4）は，それ らの先行研究を支持しているものといえよう.

以上の検討を踏まえて, 本研究では中学生の生 活の循環構造に関する仮説モデルを作成し, 構造 方程式モデリングを用いて解析した（図 5)。そ
の結果, 「始業前の生活」「学校での自覚症状」「放 課後の生活」は循環構造にある様子が確認された。 また，性差を検討するために行った多母集団同時 分析の結果, AGFI, RMSEA, AICがより良好で あった測定不変モデル（因子負荷量不変）を採択 した.さらに, 循環構造に男女差が認められない 様子も確認された，その上で, 循環する 3 つの潜 在変数を結んだパスを観察してみると,「放課後 の生活」から「始業前の生活」の推定值が最も高 值を示した。このことは, 生活習慣を改善させ, 良い循環を生みだすためには「放課後の生活」の 改善への取り組みが必要であることを示唆してい る. 実際, 田中・野井 (2016) は, 中学生を対象 とした電子メディア利用を自主的に制限する取り 組みが就床時刻を早くし, 疲労自覚症状のうち「II 群：不安定感」を軽減する様子を報告している. 併せて，生活が循環的に関連し合っているという 事実は,「放課後の生活」の改善に限らず,「始業 前の生活」「学校での自覚症状」を改善させること もまた，生活習慣の改善に寄与することを期待さ せる. その点, 始業時間を 25 分間遅らせて起床 後の時間を確保した結果, 睡眠時間は延長, 学校 での眠気, 抑うつ気分は改善したとの報告 (Boergers et al., 2014）や, 学校での体育の授業が 疲労自覚症状の訴えを減少させたとの報告（前橋 ほか，1986）は注目に值する。また, 良い生活習 慣の確立には，望ましくない生活習慣の改善より も，望ましい生活習慣の維持の方が強く影響する との報告（小林ほか, 2008）もある。これらの報 告は, 「始業前の生活」「学校での自覚症状」「放課 後の生活」のそれぞれを改善させる取り組みの手 がかりを示しているとともに, 望ましい生活習慣 の継続との連動が必要な様子を示唆している. 今 後は, 望ましくない生活を改善させる取り組みや, その成果を継続させるための持続可能な取り組み の創造が重要であると考える.

なお, 以下の 3 点は本研究の限界であり, 今後 の研究課題としたい. 1 点目は, 調査方法が質問 紙調査であったことである。主観的に評価した睡 眠と実測された睡眠では少なくない差があること が報告されている（鈴木・野井, 2015). そのため, 本研究で調査された就床・起床時刻, 電子メディ ア利用時間等についても, それらにどの程度の正 
確性があるかについては言及できない. 2 点目 は, 横断的な研究であったことである. スマート フォンの急速な普及によりインターネット依存の 問題が叫ばれるようになる等, 子どもを取り巻く 生活習慣は日々変化する。本研究の結果は, 現時 点での子どもの 1 日の生活の循環構造を検討した に過ぎない. 3 点目は, 中学生のみを対象として いることである. 小学生, 高校生で同様な結果が 得られるかについては言及できない。これら諸点 は, 本研究の課題であるとともに, 今後の研究課 題であると考える。

\section{$\mathrm{V}$ 結 論}

本研究では, 世田谷区全公立中学校に在籍する 中学 1 3 年生を対象として,「始業前の生活」「学 校での自覚症状」「放課後の生活」の妥当性を検討 し, それら生活の循環構造を確認した。 その結果, 中学生の 1 日の生活は循環構造にあり,「放課後 の生活」から「始業前の生活」への推定值が最も 高值を示す様子が確認された. 加えて，1日の循 環構造には, 男女差がないことも確認された。

以上の結果から, 良い生活の改善のためには, 「放課後の生活」の改善を目指すことが有用であ ることに加え,「放課後の生活」に比べ影響は小さ くなるものの「始業前の生活」学校での自覚症状」 を改善させることも意義があると考えられた。

\section{謝辞および付記}

本研究の実施にあたり, 対象者としてご協力いただ いた子どもたちと調查校の先生方, ならびに世田谷教 育委員会の関係諸氏に, 深謝の意を表したい。また, 的確な助言をいただいた徐広孝氏 (筑波大学附属駒 場中・高等学校), 鈴木宏哉氏 (順天堂大学)にも, 感 謝の意を表したい。 なお, 本研究は, 平成 28 年度又 ポーツ庁委託事業「子供の体力向上課題対策プロジェ クト (委託事業者：世田谷区教育委員会)」の一部とし て実施された。

\section{文献}

Boergers, J., Gable, C. J. and Owens, J. A. (2014) Later school start time is associated with improved sleep and daytime functioning in adolescents, J
Dev Behav Pediatr, 35, 11-17

Brainard, G. C., Rollag, M. D. and Hanifin, J. P. (1997) Photic regulation of melatonin in humans : ocular and neural signal transduction, J Biol Rhythms, $12,537-546$

春木 敏, 川畑徹朗 (2005) 小学生の朝食摂取行動の 関連要因, 日本公衆衛生雑誌，52，235-245

林 千代, 千 裕美, 松下慶子 (2008) 小・中学生の 朝食摂取状況と基本的生活状態との関連, 飯田女 子短期大学紀要, $25,97-114$

Higuchi, S., Nagafuchi, Y., Lee, S. and Harada, T. (2014) Influence of light at night on melatonin suppression in children, J Clin Endocrinol Metab, 99, 3298-3303

小林秀紹，鈴木美智子，小澤治夫（2008）群馬県館林 市における小学生の生活習慣と体調・学習行動の 因果構造分析, 発育発達研究, 37, 49-56

Lewy, A. J., Wehr, T. A., Goodwin, F. K., Newsome, D. A. and Markey, S. P. (1980) Light suppresses melatonin secretion in humans, Science, 210, 12671269

前橋 明, 寺坂鋭子, 中永征太郎（1986）午後の体育 授業前後における女子高校生の自覚症状の訴え スコア・フリッカー值・カウンター值・握力值の 変動, 運動 ·健康教育研究, $6,21-25$

日本学校保健会 (2014) 平成 24 年度児童生徒の健康 状態サーベイランス事業報告書

日本学校保健会（2016）平成 26 年度児童生徒の健康 状態サーベイランス事業報告書

野井真吾, 下里彩香, 鈴木綾子, 山本晃弘, 野田 耕 (2008)，「からだ学習」に関する基礎的研究一疑 問調査, 知識調査, 生活調査, 体調調査の結果を 基に一，学校保健研究，49，439-451

Noi, S. and Shikano, A. (2011) Melatonin metabolism and living conditions among children on weekdays and holidays, and living factors related to melatonin metabolism, School Health, 7, 25-34

野井真吾, 阿部茂明, 鹿野晶子, 野田 耕, 中島綾子, 下里彩香, 松本稜子, 張 巧鳳, 斉 建国, 唐 東輝（2016）子どもの“からだのおかしさ”に関 する保育・教育現場の実感一「どものからだの 調査 $2015 」 の$ 結果を基に一, 日本体育大学紀要, 46, 1-19

小澤治夫 (2004) 元気が出る学校体育活動とその要因, 教職研修, 32, 127-131

鈴木彩加, 野井真吾 (2015) 発達障害のある高校生の 睡眠状況の特徴一非接触型睡眠計測機器を用い 
て一, 発育発達研究, $66,30-3$

城 憲秀 (2002) 新版「自覚症しらべ」の提案と改訂 作業, 労働の科学, 57, 31-35

田中綾帆, 野井真吾 (2016)「ノーメディア」の取り組 みが中学生の睡眠状況・疲労自覚症状におよぼす 効果検証, 発育発達研究, $73,1-12$

田中 良, 鹿野晶子, 野井真吾 (2017) 小・中学生に おける疲労自覚症状の実態とその関連要因の検 討, 日本幼少児健康教育学会誌，2，77-85

植野香織, 田中茉奈美, 藤井千恵 (2012) 就寝前のメ ディア利用が生体リズム及び睡眠の質に与える 影響について, 愛知教育大学研究報告, 教育科学
編, 61，53-58

渡邊純子, 渡辺満利子, 山岡和枝, 根本明日香, 安達 美佐, 横塚昌子, 丹後俊郎 (2016) 中学生におけ るライフスタイルと愁訴との関連性熊本県の横 断調査から, 日本公衆衛生雑誌, 63, 113-125

Zeitzer, J. M., Dijk, D. J., Kronauer, R. E., Brown, E. N. and Czeisler, C. A. (2000) Sensitivity of the human circadian pacemaker to nocturnal light : melatonin phase resetting and suppression, J Physiol, 526 (Pt3), 695-702

(受付 : 2017 年 9 月 28 日, 受理 : 2018 年 4 月 16 日)

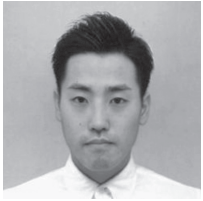

田中 良（たなかりょう）

日本体育大学大学院体育科学研究科博士 後期課程

2017 年 3 月に日本体育大学大学院体育科学研究科博士前 期課程修了後, 同年 4 月より同博士後期課程に進学. 2018 年 4 月からは日本学術振興会特別研究員 (DC2) としても 採用され, 子ども, 身体活動, 疲労等をキーワードに研究 活動に従事している. 